\title{
„MIT SZÓLNAK A SZOMSZÉDOK?” \\ AZONOS NEMÜ PÁROK CSALÁDJAI ÉS A REJTŐZKÖDÉS DILEMMÁJA
}

\section{DOI: 10.18030/socio.hu.2015.1.144}

\section{ABSZTRAKT}

Amikor egy LMBTQ személy előbújik, vagyis vállalja szexuális orientációját vagy nemi identitását családtagjai előtt, azok ugyanazzal a dilemmával szembesülnek, amelyet az LMBTQ ember saját magára nézve éppen megoldott (Kuhar 2007). A szexuális orientáció stigmája „ragadós” (Goffman 1974), vagyis közvetve az érintett személy környezetét is stigmatizálja, ráadásul Magyarországon nincsenek olyan támogató közösségek LMBTQ emberek családtagjai, mint LMBTQ emberek számára. Ezért nem ritka, hogy a család titkolni próbálja családtagjuk hagyományostól eltérő szexuális orientációját vagy nemi identitását.

Tanulmányomban azonos nemű párokkal, illetve családtagjaikkal készített etnográfiai interjúk alapján próbálom felderíteni, milyen tényezők befolyásolhatják a szülők előbújással kapcsolatos döntéseit. Az egyik ilyen körülmény a lakókörnyezet jellege: a sztereotípiákkal ellentétben falun élő szülők gyakran vállalják gyermekük azonos nemú párkapcsolatát, a kisvárosban élők viszont inkább félnek a másodlagos stigmatizációból eredő presztízsveszteségtől, és igyekeznek gyermeküket lebeszélni a nyílt önfelvállalásról. A környezet vélt vagy valós homofóbiája is befolyásolja azt, hogy egy családtag előbújik-e vagy sem.

A családtagok rejtőzködése gyakran terheket ró magára az LMBTQ személyre; kénytelen folytatni a korábban alkalmazott rejtőzködési stratégiákat, ám ez már nem a saját döntése. Mindez gyakran konfliktusokhoz vezet, illetve olyan stratégiákhoz, amelyekkel az LMBTQ személy megpróbálja kiprovokálni családtagjai előbújását. Ugyanakkor mindennek a fordítottja is előfordul: olykor éppen az elsőként beavatott családtag veszi rá az LMBTQ személyt az előbújásra a teljes család előtt. Olyan családtagokra is hozok példákat, akik az elóbújáson túl általánosságban is támogatják az LMBTQ emberek ügyét.

Kulcsszavak: család, LMBTQ, előbújás, stigma

\section{ABSTRACT}

'What will the neighbours say?' Families of origin of same-sex couples and the dilemma of the closet

When an LGBTQ person comes out to her/his family of origin, they are pushed back into the closet the LGBTQ person has just come out of (Kuhar 2007). Sexual orientation is a 'sticky' stigma (Goffman 1974), that is, it stigmatizes the environment of the person as well. Moreover, in Hungary no supportive communities 
are available for family members of LGBTQ people similar to those for LGBTQ people themselves. Therefore families frequently decide to hide the non-traditional sexual orientation or gender identity of their member.

My paper is based on ethnographic interviews with same-sex couples and their family members. I am trying to explore what factors influence the decisions of family related to coming out. I have found that, contrary to stereotypes, parents living in villages often do not mind if their child's sexual orientation comes to light, whereas small-town parents are more worried about the potential loss of prestige resulting from secondary stigmatization and try to convince their child to stay closeted. The assumed or experienced homophobia of their environment also influences family members' decision to come out.

When family members stay in the closet, the practical tasks of maintaining it still fall on the LGBTQ person; $\mathrm{s} /$ he has to continue her/his former strategies of hiding, though this is no longer her/his own decision. This often leads to conflicts or strategies that the LGBTQ person uses to provoke the coming out of her/his family members. The opposite also happens, with the family member first trusted with the information encouraging the LGBTQ person to come out to the rest of the family. I will also bring examples to family members who support the cause of LGBTQ people beyond coming out to others.

Keywords: family, LGBTQ, coming out, stigma

\section{BEVEzetÉs}

Egy 2010-es kérdőíves, az LMBTQ közösségben ${ }^{1}$ folytatott felmérés során ( $\left.n=2755\right)$ a résztvevők 47\%-a számolt be pozitív hozzáállásról szexuális orientációja vagy nemi identitása iránt testvére, 38\%-uk anyja és 24\%uk apja részéről (Dombos et al. 2011: 39). Ez jobb arány, mint az LMBTQ közösségben és azon kívül hallható közbeszédek sugallnák, amelyek gyakran feltételezik a teljes elutasítást a család, különösen a szülők részéről (Weston 1991). Ugyanakkor az LMBTQ emberek szülei még láthatatlanabbak, mint maguk az LMBTQ emberek; Magyarországon nyoma sincs olyan egyesületnek, mint az amerikai PFLAG, amely LMBTQ emberek barátait és családtagjait tömöríti. ${ }^{2}$ Rejtőzködésük azt sugallja, hogy a hagyományostól eltérő szexuális orientáció vagy nemi identitás egyfelől tabutéma, másfelől nemcsak az érintett személyt stigmatizálja, hanem annak családját is.

Goffman szerint a stigma gyakran „átragad” a stigmatizált csoport tagjáról annak közvetlen környezetére (Goffman 1974: 30). A homoszexualitás többfajta módon válhat ilyen „ragadós” stigmává. Egyrészt bizonyos elméletek örökléssel vagy a nevelés hatásával magyarázzák a homoszexualitás kialakulását (Tóth 1993: 33-36), így ha egy családban van egy meleg vagy leszbikus, egyesek az illető szüleit „hibáztathatják” ezért, vagy gyanakodni kezdhetnek, hogy más családtag is a saját neme felé vonzódik (Herdt és Koff, 2000). Másrészt a homofóbiának nemcsak az LMBTQ emberek válhatnak célpontjaivá, hanem az őket támogató heteroszexuális szimpatizánsok is (Richards 1999). Mivel ugyanakkor a nem-heteroszexuális orientáció a kívülről nem látható

1 Az LMBTQ betűszó feloldása: leszbikus, meleg, biszexuális, transznemú és queer. Szokás hozzátenni még az (interszexuális és aszexuális kifejezésekre utaló) I és A betúket is, azonban e két csoport tagjai csak az utóbbi egy-két évben (vagyis terepmunkám befejezését követően) kezdenek valamelyest láthatóvá válni Magyarországon, ezért megjelenítésüket a rövidítésben üres gesztusnak érezném és eltekintek tőle.

2 A magyar PFLAG nevű egyesületnek nem ez a profilja. Rövid ideig létezett egy rendszertelen időközönként találkozó csoport melegek és leszbikusok szülei részére, ez azonban elhalt. 
stigmák közé tartozik (Goffman 1974), viselője és annak családja egyaránt dönthet úgy, hogy titokban tartja. Ez viszont számos problémához és feszültséghez vezethet.

Tanulmányom azt vizsgálja, hogy az azonos nemú párok eredeti családjai mennyire és milyen módon vállalják a külvilág felé azt, hogy családjuknak a hagyományostól eltérő szexuális orientációjú személy (is) tagja. Az itt idézett eredmények egy nagyobb kutatás részei, amelynek során azonos nemú párok és eredeti családjuk kapcsolatát vizsgáltam és azt, hogyan befolyásolja mindez az érintettek családról alkotott képét. Előzetes interjúim és olvasmányaim alapján azt feltételeztem, hogy a környezet vélt vagy megtapasztalt hozzáállása nagymértékben befolyásolja azt, hogyan viszonyul a család az azonos nemú párhoz. Az LMBTQ közösségben - különösen annak aktivista rétegeiben - uralkodó diskurzus, amely az önfelvállalást alapvető, mindenhol követendő értéknek tekinti (D’Emilio 1998 [1983], Esterberg 1997), éles ellentétben áll azzal a (különösen hagyományos közösségekben jellemző) gyakorlattal, hogy a kínosnak tekintett vagy a család presztízsét esetlegesen aláásó információkat titkolni kell a környezet előtt (Fél-Hofer 1969). Számítottam tehát arra, hogy a család titkolózása gyakran konfliktushoz vezet a saját neméhez vonzódó családtaggal, amely konfliktus ezáltal két értékrend ütközését is mutatja.

\section{ELŐBÚJÁS ÉS REJTŐZKÖDÉS - A CSALÁD SZINTJÉN}

Az előbújás/rejtőzködés kettőssége alapvető fontosságú mind az LMBTQ emberekkel foglalkozó szakirodalom, mind az LMBTQ mozgalmak számára. Ez utóbbiak úgy tekintik az LMBTQ emberek előbújását, mint a polgárjogi küzdelem és a társadalmi elfogadás alapvető feltételét (Plummer 1997), hiszen az LMBTQ emberek láthatatlansága hozzájárul a sztereotípiák és előitéletek továbbéléséhez, míg azok, akik személyesen ismernek LMBTQ embereket, a kutatások szerint elfogadóbbak a szexuális kisebbségekkel általában (Herek 1997). Noha a szexuális orientáció heteroszexuális környezet előtti felvállalása sokáig nem volt általános jellemzője a meleg/ leszbikus/biszexuális életformának (Plummer 1997), ma már az előbújás/rejtőzködés dilemmája alapeleme az LMBTQ létezésnek. Sedgwick egyenesen úgy véli, hogy ez a kérdés a „meleg emberek” szociális életének alapvető vonása, és „a rejtőzködés episztemológiája az egész 20. században állandóságot adott a meleg kultúrának és identitásnak" (Sedgwick 2011: 24). ${ }^{3}$

Fontos megemlíteni, hogy az önfelvállalás és a rejtőzködés között átmenetek is vannak. Ezek egyike a „nyílt titok”, amikor a személy nem tesz erőfeszítéseket identitása titokban tartására, de nem is bújik elő explicit módon (Sedgwick 2011). A nyílt titok stratégiáját természetesen az LMBTQ személy családtagjai is alkalmazhatják környezetük felé. Szintén gyakran alkalmazott módszer az „összeesküvés” (collusion), amelynek esetén a családtagok megállapodnak abban, hogy bizonyos személy vagy személyek - gyakran idősek vagy gyerekek nem tudhatnak a titokról (Davies 1992). Előfordulhat az is, hogy az egyén (vagy a család) gondosan elkülöníti azokat az ismerőseit, akik előtt vállalja szexuális orientációját, és azokat, akik előtt nem - ügyelve rá, hogy a két csoport soha ne találkozzon egymással; ez az „elkülönítés” (compartmentalization)(Davies 1992: 79-80). A negyedik átmeneti formának Roman Kuhar a transparent closet (üvegszekrény) nevet adta: ${ }^{4}$ ebben az esetben az egyén előbújik, ám környezete nem vesz erről tudomást (legalábbis úgy tesz), gyakran azért, mert nem képes

3 Kovács Vera fordítása. Sedgwick a „gay” (meleg) szót ernyőfogalomnak használja a nem-heteroszexuális orientációkra általában.

4 Angolul a rejtőzködő személy in the closet, azaz szekrényben van. 
feldolgozni ezt az információt (Kuhar 2007: 43). Természetesen a különböző stratégiák átfedésben is lehetnek egymással, például az „összeesküvés” gyakran azt vonja magával, hogy a titokba be nem avatott személyek jelenlétében a szexuális orientáció tabutéma lesz („üvegszekrény”). Ezek az átmeneti formák fontos szerepet tölthetnek be az LMBTQ emberek és családjuk életében, továbbá emlékeztetnek minket arra, hogy az önfelvállalás és a rejtőzködés nem monolitikus fogalmak, hanem mindig az adott helyzet vagy személyek viszonylatában értelmezendők.

Az előbújás (coming out) tehát szituatív jelenség (Plummer 1997: 22), ugyanakkor performatív beszédaktus. A performativitás-elmélet J. L. Austin (1962) nyelvész-filozófus munkásságára támaszkodik, aki megállapította, hogy minden verbális megnyilvánulás egyben cselekvés is, amennyiben az interakció szemszögéből nézzük. Judith Butler szerint különféle identitásainkat, köztük a nemi és a szexuális identitást is, performatív kijelentésekkel és viselkedésformákkal konstruáljuk (Butler 2001; 2007). Az előbújás mint az LMBTQ identitások fontos eleme egyben részt vesz az identitás kialakításában, miközben újfajta viszonyt (pl. bizalom) hoz létre az előbújó személy és hallgatósága között. Ugyanakkor minden egyes előbújás újból kialakítja a rejtőzködés terét is (Butler 1991): nemcsak azért, mert az önfelvállalás csak ahhoz képest értelmezhető, hanem azért is, mert a titokba beavatott személy vagy személyek - esetünkben a családtagok - maguk is dönteni kénytelenek arról, hogy továbbadják-e az információt, és ha nem, milyen módokon tudják a lelepleződést elkerülni. Kuhar szavaival élve, most rájuk rakódott át annak a titoknak a súlya, amelytól az LMBTQ személy éppen megszabadult (Kuhar 2007:42). Előbújásukkal kapcsolatos döntéseiket befolyásolhatja az, hogyan viszonyulnak ők maguk családtagjuk eltérő szexuális orientációjához, illetve az is, mennyire látják elfogadónak saját környezetüket.

A performativitás elmélete nemcsak a nemi és szexuális identitásra, hanem a családra is alkalmazható. Maga Austin is egy családdal kapcsolatos mondatot - a házasságkötéskor elhangzó „igen”-t - hozza fel a performatív kijelentések egyik mintapéldájaként (Austin 1962: 13), hiszen ez puszta kimondásával családtaggá tesz két korábban nem családtagnak tekintett személyt. A választhatóság, amelyet a partnerkapcsolatok szintjén magától értetődőnek veszünk, egyre inkább jellemzi a vérségi kötelékeket is (Stone 2004). A család performatív beszédaktusokkal és cselekvésekkel fejezi ki, hogy egy adott személyt teljes értékú családtagnak tekint-e. Ennek egyik eleme lehet az, hogy mások előtt közösséget vállal-e az illetővel; ilyen értelemben a család rejtőzködése szimbolikusan másodrendű családtaggá fokozza le a saját neméhez vonzódó személyt és/vagy annak partnerét, míg ha a családtagok mások előtt nyíltan közösséget vállalnak az azonos nemű párral, azzal performatív módon a család részévé teszik őket.

\section{A KUTATÁS MÓDSZEREI}

Tanulmányom alapját kvalitatív kutatás képezi, amelyet 2007 és 2011 között végeztem a magyarországi LMBTQ közösségben. Etnográfiai interjúkat készítettem 68 olyan személlyel, akik azonos nemú párkapcsolatban élnek vagy éltek, valamint 12 olyannal, akiknek közvetlen családjában azonos nemű párkapcsolatban élő ember van (gyermek, testvér, unokatestvér, sógor). A kérdések elsősorban az önfelvállalásra, illetve az azonos nemű pár és családja kapcsolatára, vagyis a rokonsági gyakorlatokra vonatkoztak, de szóba kerültek a családra, illetve a nem-heteroszexuális orientációkra vonatkozó diskurzusok is (pl. „Milyennek látod/látja az LMBTQ emberek 
helyzetét ma Magyarországon?”, „A közbeszédekben milyen kép jelenik meg ma Magyarországon a családról?” stb.). Interjúalanyaimat részben ismeretségi körömből és azok ismerősei közül szereztem (hólabda-módszerrel), illetve felhívást tettem közzé különböző LMBTQ elektronikus levelezőlistákon, a Labrisz Leszbikus Egyesület honlapján található fórumokon, ${ }^{5}$ LMBTQ rendezvények és egyesületek Facebook-oldalain, illetve szórólap formájában a Budapest Pride LMBT Kulturális Fesztiválon. A meginterjúvolt családtagokat vagy interjúalanyaim ajánlották, vagy egyéb úton ismertem meg őket (valamilyen formában részt vettek az LMBTQ közösségben vagy egy rövid életű önsegítő csoportban, amely LMBTQ fiatalok szülei számára alakult).

A magyarországi LMBTQ közösség nem egymást személyesen ismerő emberek csoportja, hanem inkább a „képzelt közösségek” (Anderson 2006) közé sorolható. Természetszerűleg nem tartozik bele mindenki, aki saját neméhez (is) vonzódik, hiszen sokan nem vállalnak azonosságot a kisebbségi szexuális identitások valamelyikével és/vagy az LMBTQ közösséggel, esetleg nincs is hozzáférésük az azzal kapcsolatos információkhoz. A magyarországi LMBTQ szubkultúra egyik sajátossága a Budapest-centrikusság: néhány vidéki városban vannak ugyan önszerveződések és az internetes honlapokat is sok vidéki olvassa, mégis az antropológusnak sokkal nehezebb vidéki interjúalanyokat találnia. Noha tudatosan próbáltam nem budapestieket is bevonni a mintámba (például ellátogattam vidéki LMBTQ rendezvényekre és azok résztvevőit felkértem interjúra), csak 21 interjúalanyom élt terepmunkám idején Budapest határain kívül, és ezek egy része is az agglomerációban. Mégsem gondolom, hogy kutatásom aránytalanul főváros-centrikus lenne, ugyanis budapesti interjúalanyaimnak körülbelül fele vidéki származású, akiknek a családja továbbra is kisvárosban vagy falun él. Ilyen formában városi LMBTQ közösségek kutatásakor lehetőség nyílik arra, hogy a vidékit a városin keresztül tanulmányozzuk (Weston 1998). Ugyanakkor, mint alább látni fogjuk, a heteroszexuális család és LMBTQ családtagja közötti konfliktus gyakran lebontható a vidék és város ellentétére.

A magyarországi LMBTQ közösség - legalábbis az a része, amely nyilvános fizikai és virtuális terekben megjelenik - más szempontokból is viszonylag homogén. A közösségben végzett más kutatásokban (pl. Dombos et al. 2011) is felülreprezentáltak a fiatalok és a felsőfokú végzettségűek. A viszonylag jó társadalmi helyzet egyrészt az LMBTQ közeg jellemzőivel függ össze: a szegényebb rétegbe tartozók a nem-ingyenes programokat nem engedhetik meg magukat, az aktivista közegekben pedig marginalizálódhatnak, mert nem rendelkeznek olyan tudásokkal, mint a többi résztvevő (pl. az Interneten megjelenő angol nyelvű információkhoz való hozzáférés által). Ugyanakkor az LMBTQ közösségbe beilleszkedő alacsonyabb osztályból származó emberek számára éppen az értelmiségiek túlreprezentáltsága jelenthet motivációt a tanulásra és társadalmi mobilitásra (ezt több adatközlőm említette, és a cikk végén található táblázatból látható, hogy több interjúalanyom az LMBTQ közösségbe való bekerülése után, a harmincas éveiben vagy még később kezdte meg felsőfokú tanulmányait). Végül, interjúalanyaim egy része a rendszerváltás előtt kezdte felnőtt életét, amikor viszonylag nagy volt a társadalmi mobilitás lehetősége (Udvarnoky 2008). LMBTQ interjúalanyaim körülbelül felének a szülei alacsony végzettségűek, ők maguk viszont kevés (15) kivételtől eltekintve felsőfokú intézményben végeztek vagy tanulnak, gyakran családjukban elsőként.

A magyarországi LMBTQ szubkultúra életkorilag is behatárolt: 18 éven aluliakat a rendszeres programok

5 A más LMBTQ honlapokon levő fórumok vagy minimális látogatottságot mutattak, vagy - egy esetben - közzétett felhívásomat reklámnak minősítették és törölték a fórumokról. 
(szórakozóhelyek, beszélgetések) többségére nem engednek be (hivatalosan), és kevés olyan esemény van, amely az idősebb korosztályt célozza meg, akik amúgy is hajlamosabbak a rejtőzködésre. Az azonban, hogy LMBTQ interjúalanyaim több mint 80\%-a 20 és 40 év között van, tudatos döntés eredménye is. Értelemszerúen nem interjúvoltam meg olyan személyeket, akiknek fiatal koruknál fogva még nem volt tartós párkapcsolatuk, az idősebb korosztályból pedig sokaknak nincs már élő rokona, ami szintén kizáró tényező volt egy családdal való kapcsolatra fókuszáló kutatásnál. A családtagok életkora sokkal tágabb spektrumon mozog: a legfiatalabb (Zira) 20 év alatti középiskolás, a legidősebb (Zsuzsanna) betöltötte a hetvenet.

Az anonimitás különösen fontos olyan kutatás esetén, amely egy viszonylag szük közösségben történik. Ráadásul az alábbi történetekben szereplő családok közül sokan rejtőzködnek, így még jobban kellett ügyelnem arra, hogy ne váljanak felismerhetővé. Adatközlőim saját maguk választottak álnevet maguknak, és hozzátartozóik is álnéven szerepelnek; a szóba kerülő településeknek - Budapest kivételével - fantázianeveket adtam.

\section{A REJTŐZKÖDÉS MOTIVÁCIÓI}

Amikor már iszonyatosan idegesitett, hogy a nagynéném és nagybátyáim már hanyadik családi ebéden foglalkoztatnak engem azzal, hogy na és mi van a barátnömmel, akkor mondtam nekik [a szüleimnek], hogy na akkor a következö ilyen alkalommal elmondom, hogy mi van a barátnömmel. És akkor erre az volt a reakció, hogy na ilyen szerintük ne legyen. Merthogy ez egy olyan belső családi titok, vagy olyan családi ügy, amit nem kéne a szélesebb család elé tárni szerintük. (Dani)

Dani szülei úgy vélték, hogy fiuk biszexualitása csak a szúkebb családra tartozik, noha maga Dani szívesen a rokonok elé tárta volna. A közbeszédben gyakran elhangzik, hogy a homoszexualitás magánügy, ezért nem kell másnak tudnia róla (Borgos 2014); ez a hozzáállás nem veszi figyelembe, hogy a heteroszexualitást ugyanakkor nem tekintjük magánügynek, hiszen Dani rokonai is magától értetődően kérdeznek rá unokaöccsük feltételezett heteroszexuális párkapcsolatára. Dani esete egy a sok példa közül arra, hogy amikor a szülők döntenek a rejtőzködés mellett, a rejtőzködés gyakorlati megvalósításának terhe továbbra is az LMBTQ személyre nehezedik (Kuhar 2007).

Előfordul viszont, hogy az LMBTQ személy kéri meg rejtőzködésre családtagjait. Amikor Adorján fia előbújt neki, Zsuzsanna nagyon szerette volna barátnőivel megbeszélni az ezzel kapcsolatos érzéseit, de Adorján megkérte, hogy az információ maradjon a családban. Ebben a történetben az LMBTQ ember nem érezte még késznek magát a láthatóságra, így Danival ellentétben ő szorította korlátok közé szüleit. Pár évvel később már ő is nyíltabban vállalta magát és szüleinek is megengedte, hogy beszéljenek másokkal az ő szexuális orientációjáról.

Adorján története illusztrációként szolgálhat azokra a fejlődési modellekre, amelyek szerint a mások előtti önfelvállalás az LMBTQ emberek önelfogadásának egyik stádiuma (Troiden 2004). Hasonló folyamatok játszódnak le az LMBTQ emberek hozzátartozóiban is. Herdt és Koff (2000) modellje szerint az a család, amelynek valamelyik tagja előbújt, először a dezintegráció fázisába kerül, ezután a kettősség érzése jellemzi, és csak később jut el az integrációig, amelynek egyik eleme a titok másokkal való megosztása. Nem ritka, hogy az eleinte titkolózó családtag, ahogy fokozatosan elfogadja gyermeke vagy testvére szexuális orientációját, egyre 
könnyebben osztja meg azt másokkal. Erzsébet eleinte még a közvetlen családtagok (apa, testvérek) előtt is titokban akarta tartani, hogy Zsóka lánya leszbikus, mára viszont már bárki előtt felvállalja: „, ha valaki megkérdez: na mi újság, és van már a Zsókának barátja, és van már pasija és izé, akkor én mindig elmondom, hogy nincs és nem is lesz, mert ez a helyzet van pillanatnyilag” (Erzsébet). Noha a „pillanatnyilag” szó azt sugallja, hogy titkon még reménykedik lánya szexuális orientációjának megváltozásában, ennek ellenére (vagy esetleg éppen ezért) nyíltan beszél róla rokonoknak és barátoknak egyaránt.

Előfordulhat, hogy a családnak egyszerúen nincs szókincse az azonos nemű párkapcsolatokra. Judit családja ugyan most már mindent tud (ennek történetét lásd később), mégis „soha nem mondják ki ezeket a szavakat, azért az vicces, a családban soha el nem hangzana az, hogy 'meleg', 'leszbikus' vagy akármi" (Judit). A homoszexualitással kapcsolatos szavakra nehezedő tabu megnehezíti, hogy a családtagok beszéljenek másoknak erről a témáról; mint Derrida rámutat, a performatív kijelentés nem lehetséges, ha nem alapulhat egy már meglevő kulturális modellen (idézi Butler 1995:205), márpedig ennek a kisvárosi családnak vélhetően nem volt tapasztalata arról, hogyan lehet családtagjuk nem-heteroszexuális orientációjáról beszélni.

Interjúim során azonban a család rejtőzködésének leggyakoribb oka az volt, hogy féltek a környezet negatív reakciójától. Szociológiai kutatások azt mutatják, hogy Magyarországon a homoszexuális emberek elutasítása nagyobb mértékű, mint a nyugat-európai országokban, sőt több kelet-európai ország is elfogadóbb nálunk (Takács 2011). Az ilyen kutatási eredmények viszonylag ismertek, így nem meglepő, hogy interjúalanyaim többsége - akár LMBTQ emberek, akár hozzátartozóik - automatikusan homofóbiát tételez fel környezetéről. Egyes esetekben bizonyos személyekről konkrétan tudják, hogy azok ellenségesek a homoszexualitással szemben. Tulipán, egy vidéki édesanya például tesztelte unokaöccseit, mielőtt felfedte volna előttük fia melegségét, és a válaszok alapján elállt a szándékától:

És mondtam, hogy mit csinálnál, ha kiderülne valamelyik családtagról, hogy meleg? És azt mondta, hogy azonnal minden kapcsolatot megszüntetne vele. És mondtam, hogy de hát [ha esetleg] unokatestvéred vagy [ilyesmi], és azt mondta, hogy nem érdekli. Aztán van olyan fiú, aki azt mondta, hogy mindet falhoz kéne csapni, mert genetikai hibásak, ugye ez a Hugó. Mert azok nem emberek, azok állatok. Úgyhogy vannak, és ezért nem nyitok a gyerekek felé. Úgy vagyok vele, hogy hát elöbb-utóbb úgyis rá fognak jönni; viszont ha rákérdeznek, soha nem fogom én tagadni. Mert ezzel az Alexandert [a fiamat] tagadnám meg. (Tulipán)

Tulipán nem akarja fiát kitenni ellenséges reakcióknak a családon belül, ugyanakkor nem hazudna, ha nyíltan rákérdeznének Alexander szexuális orientációjára. Az általa felidézett diskurzusban a homoszexualitás az ember személyiségének olyan alapvető, mindent meghatározó része (Foucault 1999), amelynek megtagadása egyenértékű lenne a homoszexuális személy megtagadásával. A „nyílt titok” technikája lehetőséget nyújt Tulipánnak arra, hogy egyszerre kiálljon a fia mellett és megvédje őt a homofóbiától.

Vannak kiemelten homofóbnak megélt közegek, ahol a rejtőzködés különösen indokoltnak tűnik. Magyarországon az iskola az egyik legelutasítóbb közeg az LMBTQ emberekkel szemben: egy 2007-es diszkriminációs kutatás (LMBTQ minta, n=1122) válaszadóinak 33\%-a tapasztalt diszkriminációt az általános és 49\%-a a 
középiskolában (Takács et al. 2008). ${ }^{6}$ A gyereket nevelő azonos nemú párok tapasztalataiból az is kiderül, hogy a „ragadós” stigma miatt az LMBTQ emberek heteroszexuális családtagjai sem védettek az iskolai diszkriminációval és zaklatással szemben (Béres-Deák 2012). Nem meglepő tehát, hogy mintámban egyetlen családtag sem beszélt hozzátartozója nem-heteroszexuális orientációjáról az iskolában; Zirát egyenesen nővére, Zsóka kérte meg erre, nehogy ő (Zira) szenvedjen hátrányokat miatta. Ebben az esetben az iskola homofóbiája nem feltételezés: Zirának több heves vitája volt egyik tanárával, aki szerint a melegek nem emberek. Tulipánéhoz hasonlóan ez az eset is arra példa, hogy a rejtőzködés nem zárja ki az LMBTQ családtag melletti harcos kiállást: Zira nem említette a tanárnak nővére leszbikusságát, csak általában szólalt fel az LMBTQ emberek védelmében.

Zira és Tulipán konkrét homofób megnyilvánulásokat tapasztalt a környezetében, és ez is hozzájárult a rejtőzködéssel kapcsolatos döntésükhöz. Gyakori azonban, hogy a család csak feltételezi környezete homofóbiáját, minden előzetes tapasztalat nélkül. Ez a félelem és a hatására tett lépések erősen függnek a település fajtájától.

\section{REJTŐZKÖDÉS FALUN ÉS VÁROSON}

Ök [a párom szülei] egy kisvárosban laknak, ahol őket, föleg a papát, majdnem mindenki ismeri. [...]és ez nekik érezhetően kellemetlen lenne, hogyha - legalábbis ők úgy gondolják - hogyha ez [a mi leszbikus kapcsolatunk] ott kiderülne. Tehát [nem hallható] lettem fölszólitva kvázi indirekt módon, hogy őnáluk ezt a fülbevalót [szivárványos] lehetöleg ne hordjam. Vagy a mondjuk a szivárványos karkötőt ne hordjam már. [...]azt szoktuk mondani, amikor rákérdeznek [a szomszédok], hogy hát ez mittudomén, tehát hogy nem mondjuk azt, hogy én ott lakom. Hanem azt mondjuk, hogy sokat vagyok ott. [...]És emiatt kell nekem most teljesen visszavonulnom, hogy úgy mondjam, a nyilvánosságtól. [...] Mondjuk az, hogy ne menjek mittudomén ne szerepeljek [leszbikus rendezvényeken készített] fényképeken például, mert akkor, tehát hogyha valahol valaki bárki meglátja azt a fényképet és engem megismer, hogy hozzá én vagyok az, és akkor kiderül [a városban], hogy én ki vagyok vagy mit csinálok. (Andrea)

Andrea párjának családja egyáltalán nem viszonyul ellenségesen a leszbikus párhoz: „én ott abszolút családtag vagyok" - állítja Andrea, és különböző közös programokat említ ennek igazolására. Arra azonban ügyelnek, hogy a kisvárosban, ahol laknak, ne derüljön ki a párkapcsolat jellege. Emiatt nemcsak korlátozzák Andrea önkifejezését (leszbikus jelképek viselése) és szubkulturális rendezvényeken való részvételét (vigyáznia kell, nehogy lefotózzák), de ráadásul a párnak úgy kell tennie, mintha nem is élnének együtt, hanem Andrea csak egy gyakran ott alvó látogató volna. Mindennek az az oka, hogy a szülők félnek a város megbecsülésének elvesztésétől. Ezzel a félelmükkel nincsenek egyedül: József édesanyjának első reakciója fia előbújására az volt, hogy ezentúl nem mer majd kimenni az utcára. Mivel kiterjedt családja ugyanabban a kisvárosban él, mint ő, számított rá, hogy valamelyikük előbb-utóbb elterjeszti a hírt, és minthogy őt foglalkozásából adódóan mindenki ismeri, elveszíti a városlakók megbecsülését. Érdekes módon aggodalma akkor hagyott alább, mikor megtudta, hogy a helyi lelkész fia drogfüggo; az, hogy köztiszteletnek örvendő lakosok családjában is lehet „fekete bárány", megnyugtatta, hogy ő sem fog stigmatizálódni fia melegsége miatt.

Azokban az esetekben, ha az LMBTQ személy nem lakik családjával azonos településen, viszonylag köny-

$6 \mathrm{Az}$ adatok értelmezéséhez érdemes azt is figyelembe venni, hogy az LMBTQ emberek közül sokan még nincsenek tisztában szexuális orientációjukkal általános-, sőt középiskolás korukban, illetve nem vállalják azt föl társaik és tanáraik előtt. 
nyű szexuális orientációját titokban tartani; Andrea párjának szülei is csak akkortól szabtak feltételeket, amikor lányuk és párja az ő városukba költöztek. A médianyilvánosság - amelytől ez a család szintén tart, mivel Andrea rendszeresen részt vesz leszbikus rendezvényeken - azonban ilyen esetekben is eljuthat a család környezetéhez. Amikor Liza egy rádióműsorban nyilatkozott leszbikusként, kisvárosi boltos apja követelte, hogy változtassa meg a nevét, nehogy ő elveszítse a vásárlóit lánya nyilvános önfelvállalása miatt. A különböző vezetéknév szimbolikusan megszüntetné ${ }^{7}$ kettőjük között a családi köteléket, így egyfajta negatív performatív gesztusnak is felfogható.

A környezetük véleményétől rettegő szülők ennél extrémebb lépéseket is tehetnek. Edmund egy nap arra érkezett haza a szülői házhoz, hogy holmija össze van csomagolva a küszöbön, és anyja ultimátum elé állította: „mondta, hogy vagy megváltozok, vagy elmegyek” (Edmund). Edmund szerint anyja azért cselekedett így, mert félt a környezet reakciójától: „hogy mit gondolnak a szomszédok, és ezen agyal. Hogy mit gondolnak majd a nagyszülök meg a rokonság" (Edmund). Azt is kihangsúlyozza, hogy szerinte anyja félelmének a falusi környezet az oka: „anyukám faluról származik, és ilyen, szerintem azért” (Edmund).

Edmund története szerencsésen végződött: már a buszon ült útban párja falujába, amikor sms-t kapott édesanyjától: „szeretlek, gyere vissza!”. Ez a történet példázhatja azt, hogy a szülői szeretet győzedelmeskedik a lelepleződéstôl való félelem fölött, de az is lehet, hogy a kettő azonos irányba mutat. Egy kis faluban ugyanis könnyen feltûnhet, ha valakinek az addig otthon élő egyetemista fiát hirtelen nem látják többé; a szülók vagy hazudni kényszerülnek, vagy beismerni, hogy kitagadták. Ez utóbbi viszont, a szülőktől elvárt feltétlen szeretet fényében, magyarázatot igényel, vagyis a család kénytelen lenne felfedni a stigmát, amelynek titkát megőrizni kívánta. ${ }^{8}$ Valami hasonló történt a vidéki városban élő Tulipánnal, aki párjához költözött és korábbi lakását meleg fiának adta, mert nem bírta elviselni a gondolatot, hogy vele egy lakásban homoszexuális szexuális tevékenység folyik. Nővére mindebből csak annyit látott, hogy Tulipán magára hagyta 18 éves fiát (noha továbbra is eltartja és elvégzi nála a házimunkát), és önzéssel vádolta, mondván, hogy párkapcsolatát anyai szerepe elé helyezte. Mivel az anyaság alapvető konstruáló eleme a gyermekek igényeinek kielégítése és saját igények feladása (Lawler 2000), egy ilyen kijelentés kétségbe vonja Tulipán anyai státuszát. Tulipán kénytelen volt beszélni nővérének fia melegségéről, hogy tettét elfogadtassa.

Nem minden vidéki család próbálja azonban elrejteni környezete elől az azonos nemú párkapcsolatot. Viola szülei a „nyílt titok” stratégiáját választották: szívesen látják lányuk barátnőjét és annak fiát szüretre, de nem árulták el a falubelieknek a kapcsolat jellegét. Havana falusi családja nonverbális eszközökkel adja környezete tudtára, hogy lányuk nőpárjának, Riberának a kislányát családtagnak tekinti.

Karácsonykor ugye volt az oviba fényképezés, ugye van ez a szokás, hogy „boldog karácsonyt”, aranyosan mosolygó képpel. És hát mondom, ajándékba minden rokonnak, Havana rokonait is beleértve, csináltattunk ilyen képet. Az anyukája a munkahelyén rakta ki a Havana fényképe mellé. A nagymamája a dicsőségfalra [...]. Az apukája az a konyhakredencre, hogy aki belép a lakásba, mindjárt látja. Úgyhogy mindenkinél kinn van a kislányom, és tényleg mint az unokájukat, úgy szeretik. (Ribera, 30)

7 Liza ugyanis nem változtatott nevet.

8 Nem állítom természetesen, hogy Edmund édesanyjának ez volt az (egyetlen) motivációja, amikor fiát visszahívta. 
Sontag (1999) szerint a fénykép egyik legfontosabb funkciója, hogy dokumentálja a családi élet folytonosságát. Havana szülei és nagyanyja egyrészt olyan helyekre tették ki a kislány képét, ahol bármely ismerős vagy kolléga láthatja, másrészt ahol hagyományosan családtagok képei szerepelnek. A fénykép kitétele ez esetben a családba való befogadás performatív gesztusa, amit Ribera verbálisan is megerősít: az interjú egy másik pontján Havana szüleit és nagyszüleit egyaránt kislánya nagyszüleinek nevezi.

Előfordul, hogy az azonos nemű pár jobban félti családtagjait a ragadós stigmától, mint a családtagok maguk. Interjúnk idején Félix már hat éve együtt élt párjával, Krisszel, de csak egy hónappal korábban vitte el őt először a szülőfalujába, nem akarta ugyanis szüleit kínos helyzetbe sodorni. „Én féltem, hogy mit szólnak a szomszédok. És utána anyukám megerősitett benne, hogy hát őket nem érdekli” (Félix). Ebben az esetben nem a szülő, hanem biszexuális gyermeke tartott a környezet homofóbiájától. Félix kisvárosban él, és feltételezte, hogy egy kisebb településen jobban elítélik az azonos nemű kapcsolatokat; ez hasonlít Andrea érveléséhez, aki korábban Budapesten lakott, ezért megérti párja szüleinek rejtőzködését: „értem én azt, hogy ugyanolyan nyilltsággal nem lehet vállalni [a leszbikusságot], mint mondjuk itt Pesten ${ }^{9}$ lehetne vállalni" (Andrea).

A fenti logika szerint, minél kisebb a település, annál erősebb a homofóbia általában, és annál jobban akarnak rejtőzködni az azonos nemú párok hozzátartozói. Ezt a közhiedelemben élő elképzelést nem támasztják alá a szociológiai kutatások, amelyek szerint Nyugat-Európa néhány nagyvárosában (talán a multikulturális környezet miatt) kevésbé elfogadóak a homoszexualitással, mint pl. a kisebb városokban (Takács 2011). A fenti történetek közül Liza, József és Andrea lelepleződéstől rettegő családja kisvárosban, míg az azonos nemű párt nyíltan vállaló családok (Viola, Félix és Havana szülei) falun élnek. A különbségre az egyik lehetséges magyarázat, hogy egy kisvárosban sokkal könnyebb eltitkolni egy azonos nemú párkapcsolatot (és különösen együttélést), mint egy faluban, ahol a lakosok napi szinten érintkeznek egymással, a falusi szülők tehát esetleg meg sem próbálkoznak a rejtőzködéssel. Az is elképzelhető, hogy éppen a napi érintkezés miatt a falusiak gyerekkorától fogva közelről ismerik a saját neméhez vonzódó személyt, és az illető szexuális orientációja nem változtatja meg a róla alkotott képet; Sándor nevű interjúalanyom ennek tudta be, hogy teljes elfogadásra talált szülőfalujában, amikor férfipárjával együtt visszaköltözött oda. Egy kisváros lakói közt esetleg kevésbé szoros a személyes kapcsolat, és nagyobb fontosságot kapnak a státuszok, mint az Andrea, József és Liza történetében meg is jelenik.

Andrea - hasonlóan sok más LMBTQ személyhez - tiszteletben tartja családjának a rejtőzködés iránti igényét, ahogyan Zsuzsanna is tiszteletben tartotta fia kívánságát, hogy melegsége maradjon családi titok. Sok családban azonban éppen a rejtőzködés dilemmája vezet konfliktusokhoz az LMBTQ személy és családtagjai között.

\section{A REJTŐZKÖDÉS IGÉNYE MINT KONFLIKTUSFORRÁS}

[A húgom] elfogadja és föl is vállalja a barátai elött is meg mindenhol. Olyannyira, hogy kirakta a Facebook oldalára a „Nővéremék esküvője”10 címü fotóalbumát, amin azért kikerekedett a szemem, de [nevetünk]. [...] Tehát ő úgy rakta ezt ki, hogy állati büszke volt; bár nem kérdezett meg, hogy ez mehet? De hát nem, mindegy végülis, mai napig kinn van egyébként. (Tünde)

\footnotetext{
9 Az interjú Budapesten készült.
}

10 Tünde és párja bejegyzett élettársi kapcsolatot kötöttek, amelyet házasságként emlegetnek, a ceremóniát pedig esküvőként. 
Tünde nem hatalmazta fel húgát, hogy a Facebook nyilvánossága elé tárja az ő nőkapcsolatát, és egy kicsit kényelmetlenül is érzi magát amiatt, hogy ez így köztudottá vált. Az esemény mégsem okozott komoly konfliktust, mert Tünde, akárcsak Ribera, értékelte a fényképek kihelyezésének gesztusértékét, amint azét a tényét is, hogy húga „esküvő"-ként hivatkozik az ő bejegyzett élettársi kapcsolatára, verbális szinten megteremtve a magyar jog által nem engedélyezett egyenlőséget. Sok más LMBTQ interjúalanyomhoz hasonlóan Tünde úgy véli, a teljes elfogadás jele, ha családtagjai nem titkolóznak környezetük előtt az ő kapcsolatát illetően. Ezenkívül ritkábban fordul elő, hogy az LMBTQ személy rejtőzködne és családtagjai nem (bár Zsuzsanna esete pont erre példa); sokkal gyakoribb az, hogy az LMBTQ személy szeretné nyíltabban megélni párkapcsolatát, de családja visszatartja ettől.

A személy meleg/leszbikus és heteroszexuális közegeinek elkülönítése (Davies 1992) első pillantásra jó megoldás lenne erre a problémára. Sok azonos nemú pár azonban szeretné bevonni párját eredeti családjába, és mély fájdalmat okoz neki, ha ebben korlátozzák. Vándor esetében a konfliktus akkor robbant ki, mikor egy mútét kedvéért hazautazott szülővárosába párja, Rozi kíséretében. Vándor édesanyja pánikba esett attól a lehetőségtől, hogy környezete rájön a két nő kapcsolatának jellegére.

[Anyám] azt mondta, hogy ő ezt így nem tudja csinálni, és hogy menjen haza a Rozi.[...] És akkor még ráadásul azzal is tetézte a dolgot, hogy még délután - reggel 8-kor mütöttek-délután visszajött vagy így kora este, és akkor nekem rendezett még egy külön jelenetet arról, hogy én nem várhatom el töle, nem várhatom el senkitöl, hogy ezt elfogadja, ahogyan én élek. És hogy hagyjam a pesti életemet Pesten, és hogy képzeltem azt, hogy [nem érthető]. És akkor így kvázi, nem mondta ki, de az egész erről szólt, hogy válasszak. És akkor én választottam. (Vándor)

Vándor Rozit választotta: egy évig alig tartott kapcsolatot édesanyjával, mígnem az anya megtette az első lépést és meghívta a párt magához. Vándor szerint anyja azért esett pánikba, mert félt, hogy a városban élők számára nyilvánvalóvá válik a kapcsolat leszbikus jellege, ha Rozi is ott van a kórházban. Nem sokkal később viszont rászánta magát és beszélt lánya leszbikus kapcsolatáról néhány barátjának és munkatársának, akik nem ítélték el emiatt.

Tehát azt látom, hogy ő azért elég sok pozitiv megerösitést kap, meg a munkahelyén vagy azokban a közegekben, ahol megfordul, öt szeretik. Tehát hogy én azt gondolom, hogy reálisan nem fordulhat meg a fejében az, hogy emiatt őt bárki elítéli vagy rosszat gondoljon róla. És az a jó, hogy most meg már úgy gondolja, hogy másoknak meg nincs köze hozzá. Tehát hogy ez miért derülne ki a sarki füszeresnél például? Vagy nemtom. Vagy mondjuk a szomszédok, miért tudnák meg? Most már nem érdekli, hogy mit gondolnak attól, hogy félévente egyszer megjelenek, és csak azt látják a szomszédok, hogy mindig növel jelenek meg, és mindig ugyanazzal. Tehát ilyen probléma nincs. (Vándor)

Vándor magyarázata anyja pálfordulására kétrétű. Úgy véli, hogy azok részéről, akik anyját jól ismerik, nem áll fenn az elutasítás vagy a presztízsveszteség lehetősége; akik viszont kevésbé vannak közeli kapcsolatban vele, azokhoz el se jut az információ, illetve nem számít a véleményük. Ez a hozzáállás párhuzamba állítható azzal a jelenséggel, hogy sok LMBTQ ember a hozzá legközelebb álló személyeknek (pl. szúkebb családjának) később és nehezebben bújik elő, mint távolabbi ismerősöknek, mert csak az előbbiek reakciója fontos nekik (Weston 1991). 
Vándor narrativájában előkerül a „választás” gondolata. A „választott család” fogalma Kath Weston (1991:112) amerikai antropológus munkássága nyomán terjedt el mint a meleg és leszbikus szubkultúra egyik jellemzője: ennek tagjai gyakran párjukat, ex-partnereiket és barátaikat inkább tekintik családtagnak, mint vér szerinti rokonaikat, különösen, ha azok elutasítóak szexuális orientációjukkal szemben. Vándor az interjúban élettársát nevezte meg első helyen családtagjai között, és hajlandó volt megszakítani a kapcsolatot anyjával, amikor az - a rejtőzködés kényszere miatt - nem fogadta be őket mint párt. Története példa arra, hogy az LMBTQ emberek önfelvállalása láthatóvá teszi a családi kapcsolatok törékeny és választható voltát (Weston 1991).

A család rejtőzködésével szemben kevésbé radikális, ám hasonlóképpen látványos módon lépett fel Dani. Mint láttuk, szülei megkérték, hogy ne beszéljen férfikapcsolatáról a rokonoknak, így újra ki lett téve további kellemetlen kérdéseknek. Ezúttal azonban taktikát változtatott:

És akkor amikor, mint ahogy az várható volt, a következő ilyen szélesebb családi összejövetelen megkérdezték, hogy mi a helyzet a barátnömmel, akkor mondtam nekik, hogy na erre a kérdésre anya válaszol. És akkor ő elmondja. Hogy mi a helyzet. És akkor azzal a mozdulattal fölálltam és kimentem. (Dani)

Dani performatív módon áthelyezte a rejtőzködés terhét édesanyjára, arra a személyre, aki azt tulajdonképpen fenntartani akarta. Egyúttal feloldotta azt a dilemmát, amely az LMBTQ identitás nyílt vállalása mint szubkulturális elvárás és politikai stratégia, illetve a család rejtőzködés iránti igénye között fennállt. Ez a dilemma komoly belső konfliktusokat okoz azok számára, akik a család kérésére beleegyeznek a rejtőzködésbe. „Ez olyan fura dolog, hogy vállalom is a kapcsolatot meg nem is vállalom a kapcsolatot" - vallja be Andrea. Nemcsak amiatt érzi kényelmetlenül magát, hogy korlátoznia kell a leszbikus közösségben való részvételét, hanem azért is, mert úgy érzi, a rejtőzködéssel párkapcsolatát tagadja meg.

Ha egyes rokonok vagy ismerősök elől rejtegetni kell az azonos nemú párkapcsolatot, az gyakran azzal jár, hogy az LMBTQ személy párja nem vehet részt teljes mértékben a család életében. A családi összejövetelek, különösen a karácsony, olyan alkalmak, amikor a család szimbolikusan kinyilvánítja összetartozását. Ildi például mélyen fájlalja, hogy (most már ex-)barátnőjének szülei, noha kedvesek voltak vele, sosem hívták meg családi összejövetelekre; emiatt úgy érezte, nem fogadják be igazán. Tulipán maga is szenved attól, hogy a közös karácsonykor nem hívhatja meg fia párját (a fent említett homofób rokonok miatt), ezért azt fontolgatja, hogy véget vet a nagycsaládi karácsonyoknak. Más családok megpróbálják összeegyeztetni a rejtőzködést az azonos nemú partner szimbolikus befogadásával. Norbi szülei például befogadták fiuk (most már ex-)párját, Istvánt, viszont a nagymamának nem akartak beszélni a meleg párkapcsolatról. Karácsony este tehát a nagymamát viszonylag korán hazavitték a saját lakásába autóval, és István csak ezután csatlakozhatott az ünneplő családhoz. Ezáltal sem István, sem a nagymama nem tölthette a szentestét végig a családdal; így az a rokon, aki elől titkolják a homoszexuális kapcsolatot, ugyanúgy perifériára szorulhat a családon belül, mint az azonos nemű partner. ${ }^{11}$

Norbi szülei nemcsak megbonyolították családi ünnepüket, de bizonyos értelemben rokoni kötelezettségüket is feláldozták a rejtőzködés miatt, több interjúalanyom ugyanis elvárásként fogalmazta meg azt, hogy idős, egyedülálló rokonokat nem szabad szenteste egyedül hagyni. A rejtőzködés a családot nemcsak az azonos 
nemű pártól vághatja tehát el, hanem más rokonoktól is. Judit édesanyja éppen a rokoni elvárások és értékrend miatt kényszerült előbújásra, amikor lánya mesterséges megtermékenyítés útján teherbe esett.

Volt kettő temetés is a terhességem alatt sajnos. [...] És [a rokonok] láttak terhesen. Az nagy sértés lett volna, ha nem megyek el, de ha elmegyek, akkor kiderül. Ritkán is szoktak velem találkozni, de akkor ugye ott nem volt mit titkolni tovább. És akkor így anyukám nagy nehezen valahogy elmondta nekik, hogy mi van. Talán azt gondolta, hogy még mindig jobb, hogyha tudják az igazságot, mint hogyha azt gondolják, hogy valami megesett leány vagyok, akinek nincs férje, és nagy a hasa, milyen szégyen! (Judit)

Az előbújás alternatívája ebben az esetben a rokoni kötelességek olyan mértékú megszegése lett volna, ami mind Juditra, mind szüleire rossz fényt vet. Judit anyja szerint a házasságon kívüli terhességet rokonai nehezebben fogadták volna el, mint a leszbikusságot; ez összecseng azokkal a kutatásokkal, amelyek szerint a lányanyákat még a XX. század második felében is elutasítás fogadta Magyarországon (Tóth 2008; Somlai 2002: 76-79; az utóbbi esettanulmány ugyanabból a régióból származik, ahol Judit szülei élnek). Egyébként, akárcsak Vándor esetében, az édesanya teljes elfogadást tapasztalt környezete részéről; a stigma nem bizonyult olyan ragadósnak, mint gondolta.

\section{A VÁLLALÁSTÓL A TÁMOGATÁSIG}

Mondjuk ő [a húgom] nem állna ki; én többször hívtam, és ő - nem állna ki. Melegfelvonuláson sem. A meleg tesójáért. Vagy, elfogad engem, meg volt egyszer egy vitánk és azt mondtam rá, hogy ő utálja a melegeket, és akkor mondta, hogy nem, nem utálja, de ez nem az ő harca, és ő így nem. (Eszter)

Noha a család számára gyakran nehéz lépés környezete előtt felvállalni LMBTQ családtagját, maga az LMBTQ személy nem mindig elégedett ezzel. Eszter azt várná húgától, hogy nyilvánosan is vállaljon közösséget vele és a hasonló helyzetben levőkkel; ismerje fel, hogy „ez az ő harca” is azáltal, hogy családjában meleg ember van. Herdt és Koff (2000) szerint azok a családok, akik valóban képesek el- és befogadni nem-heteroszexuális családtagjukat, felismerik a nyílt önfelvállalás (coming out) értékét, és ezt azzal is kifejezik, hogy fellépnek az érdekében szűkebb környezetük előtt vagy akár az LMBTQ mozgalom szövetségeseként.

Kutatásom tanúsága szerint Magyarországon is vannak családtagok, akik megfelelnek ennek az elvárásnak. ${ }^{12}$ Több interjúalanyom beszámolt arról, hogy valamelyik családtagja elment a melegfelvonulásra vagy megpróbált egy kezdetben ellenséges családtagot meggyőzni, hogy fogadja el őt; láthattuk például, hogy Tulipán lazítani kíván a kapcsolatán olyan rokonokkal, akik elutasítják a homoszexualitást. Talán a legharcosabb kiállást egy roma édesapa mutatta, aki saját fivérével fordult szembe lánya érdekében:

Például mondta nagybátyám, hogy én elmehetek hozzájuk, de ha eszek náluk, akkor utána kidobja a tányért meg a kanalat. Így erre apukám megkérdezte, hogy szerinted mivel koszosabb egy olyan nö, aki nővel él, mint egy olyan férfi, aki egy nővel él? Szerinte? És akkor mondta neki, hogy „hát akkor semmivel". És mondta apukám, hogy nincs szar a küszöbön, de akinek nem tetszik, hogy a lánya milyen, annak nem kell bejönni hozzánk. (Törpi)

12 Az általam meginterjúvolt családtagok között természetesen felülreprezentált ez a kategória, hiszen egy antropológusnak interjút adni ebben a témában feltételez valamilyen szintű nyílt felvállalást és sok esetben az LMBTQ emberek ügye melletti elkötelezettséget. 
A roma közösségben közismerten fontosak a rokoni szálak, amelyeknek egyszerre van identitás-megőrző és gyakorlati szerepük (Stewart 1997). A roma kultúrában fontos szimbolikus jelentéssel bíró tisztaság motívuma (Stewart 1997) szolgál keretül a leszbikusság elfogadható vagy elfogadhatatlan volta fölötti vitának. A tányér és kanál eldobása (illetve annak beígérése) performatív módon tisztátalannak minősíti a leszbikus nőt, amire az apa az érvelést követően egy másik performatív gesztus, a házából való kirekesztés fenyegetésével reagál. Noha az LMBTQ közösségben gyakori vélemény, hogy a roma közösség éppen hagyományos jellege miatt kirekeszti a homoszexuálisokat, ${ }^{13}$ ez a történet a családtag iránti szolidaritást példázza, ráadásul egy másik rokonnal szemben.

Míg Törpi édesapja egy adott helyzetben kelt lánya védelmére, Eszter az LMBTQ ügyek általános támogatását várná el testvérétől. Vannak testvérek, akik megfelelnek ennek az elvárásnak; láthattuk, hogy a középiskolás Zira tanárával is szembehelyezkedett az LMBTQ emberek védelmében. Ivettnél a melegellenes kijelentések vagy akár csak a sértő „buzi” szó használata válóokot jelentenek:

Volt egy barátom, aki viszonylag [gyakran] mondta azt, hogy nem volt gondja a melegekkel, viszont mindig mondta, amikor valami nem tetszett neki, hogy ez buzis. Tehát olyanra, ami nem is, köze sincs hozzá, vagy mondjuk hogy ez egy ilyen buzi dolog vagy buzi tévé meg ilyenek. Tehát hogy úgy tényleg nem ilyen, semmi köze nem volt, de azért ilyen káromko... szitokszónak használta. Na én mondtam neki, hogy hát ez bébi, ez így kettőnknél nem fog müködni, hogyha ezt mondod. (Ivett)

Biszexuális nővére hatására Ivett magáévá tette az LMBTQ emberek ügyét; az eltérő szexuális orientációk elfogadását olyan mértékben „világlátása alapkövévé” (az ő szavai) tette, hogy el sem tud képzelni párkapcsolatot egy homofób emberrel. Fiatal egyetemistaként ugyanakkor viszonylag könnyű hasonló gondolkodású embereket találnia; amerikai kutatások (Powell et al. 2010) szerint a fiatalabb korosztály és az egyetemisták vagy egyetemet végzettek nyitottabbak az alternatív családformákra, köztük az azonos nemú párkapcsolatokra is. Benő megdöbbenésére bátyjai nemhogy stigmatizálódnának az ő melegsége miatt a környezetükben, hanem még előnyt is kovácsolhatnak belőle:

Ök engem mint ilyen titkos csajozó fegyvert használnak. Merthogy a lányoknál az állitólag valamilyen szuper plusz, hogy „ja, és van egy meleg öcsém”. [utánozza] „Jaj, tényleg, és nem, és izé, és ez csak igy tudsz róla beszélni?” „Ja persze, hát nincs vele semmi gondom." (Benő)

A fivérek stratégiája azokra a (kutatások által is alátámasztott) sztereotípiákra épül, amelyek szerint a nők elfogadóbbak a homoszexualitással szemben, mint a férfiak (pl. Franklin 1998). Egyfelől feltételezik, hogy a lányok elfogadóak a melegséggel szemben, másrészt arra számítanak, hogy ők mint meleg öccsüket elfogadó fiatalemberek kuriózumnak számítanak. Úgy fest, hogy az általuk látogatott fiatal fővárosi közegnek legalábbis egy részében a melegség már nem terheli stigmával sem magát az érintett személyt, sem annak családtagjait.

\section{ÖSSZEFOGLALÁS: FÉLELMEK ÉS DÖNTÉSEK}

A fenti történetekből kiderül, hogy az előbújás nemcsak az LMBTQ emberek, hanem családtagjaik számára is komoly problémát jelent. Az ő esetükben külön nehezíti a helyzetet, hogy nincs olyan támogató közeg,

13 Nem tudok elkészült kutatásról ebben a témában; másik roma adatközlőm nem vállalja szexuális orientációját nyíltan a családja előtt, így ő nem képezhet összehasonlítási alapot. 
amelyben hasonló helyzetű emberekkel megoszthatnák tapasztalataikat. Ugyanakkor napi szinten kerülnek olyan helyzetbe, amikor dönteniük kell, mesélnek-e régi ismerősöknek vagy rokonoknak családtagjuk azonos nemú párkapcsolatáról, különösen, ha ezek az ismerősök és rokonok velük többet találkoznak, mint nem-heteroszexuális családtagjukkal: „őtőle kérdezik azt, hogy mi van a lányával, hogy van-e valakije, és [...] neki kell válaszolni" - magyarázza Vándor édesanyja reakcióját. Jellemzően a szülők és nagyszülők nagyobb arányban laknak kis településen, mint LMBTQ leszármazottaik;; így egyrészt rejtőzködniük is nehezebb, másrészt a vidéki emberek vélt homofóbiájáról keringő közbeszédek miatt kevésbé mernek előbújni. Láthattuk, hogy a település típusa is befolyásolhatja az előbújást: falusi szülők - talán kényszerből, talán a személyes kapcsolatokra alapozva - hajlandóbbak felvállalni gyermekük szexuális orientációját környezetük előtt, mint a kisvárosban élők, ahol a presztízs és annak elvesztésétól való félelem nagyobb szerepet játszik a döntésben.

Láthattuk ugyanakkor, hogy egyáltalán nem minden családra jellemző az a mértékű rejtőzködés, mint Andrea párjának szüleire. Havana, Viola és Félix szülei nem törődnek azzal, ha környezetük tudomást szerez gyermekük azonos nemú párkapcsolatáról; Erzsébet, Tulipán és Vándor édesanyja a kezdeti titkolózástól eljutott a teljes (vagy legalábbis nagyobb) nyíltságig. Ezek a szülők magától értetődően terjesztették ki az azonos nemú párra és annak esetleges gyerekeire a család fogalmát, így az ahhoz kapcsolódó gyakorlatokat és elvárásokat is, amelyek egy része - például a fényképek elhelyezése a családi fotók között - performatív módon jelzi az összetartozást. A fiatalabb generáció egyes tagjai - mint Benő fivérei vagy Ivett - igyekeznek ismerőseiket úgy megválogatni, hogy ne kelljen tartaniuk LMBTQ családtagjuk és általa esetleg önmaguk negatív megítélésétől. Ezekben az esetekben a családtagok döntésén múlik a felvállalás mértéke.

Maguk az LMBTQ emberek is befolyásolhatják azonban, hogyan dönt családjuk a rejtőzködéssel kapcsolatban. Előfordul, hogy lebeszélik családtagjaikat az előbújásról, akár mert ők maguk még nem készek szexuális orientációjukról beszélni a tágabb környezet előtt (Adorján), akár mert a családtagot féltik a homofób reakcióktól (Zsóka). Gyakoribb viszont, hogy a rejtőzködés ellen próbálnak hatni, hiszen annak terhét nekik is cipelniük kell. A technikák igen változatosak lehetnek: Vándor a családi kapcsolat fenntartásának feltételéül szabta párja befogadását, míg Dani olyan helyzetet teremtett, amelyben édesanyjának sokkal nehezebb lehetett megtartania a titkot. ${ }^{15}$ Közvetve befolyásolta a család előbújással kapcsolatos döntését Félix, aki évekig nem vitte haza a párját, illetve Judit, aki nem volt hajlandó megszegni rokoni kötelességeit pusztán azért, hogy terhessége ne derüljön ki a városban.

Láthatjuk tehát, hogy az azonos nemú párkapcsolatok elfogadottsága nem egy monolitikus, állandó külső tényező. Egyrészt ugyanannál a személynél is több aspektusa lehet: Tulipán viszolyog a homoszexualitás testi oldalától, de szükség esetén harcosan kiállna meleg fia mellett. Másrészt a nem-heteroszexuális orientáció stigmájával élők - legyen az maga a nem-heteroszexuális személy vagy valamelyik hozzátartozója - befolyásolhatják a környezet reakcióját. A szülók olykor hajlandóak előbújni, ha ennek alternatívája gyermekük elvesztése vagy családi konfliktus lenne. Ha ez az előbújás olyan módon történik, hogy az azonos nemú párt integrálják a társadalmilag elfogadott családi struktúrákba és tevékenységekbe, a környezet hajlamos elfogadni a helyzetet. Azok közül a csa-

14 Az LMBTQ emberek nagyvárosokba történő migrációjáról lásd: Weston 1998: 31-49; Magyarországon ehhez még hozzájárul a fiatalabb generáció Budapestre költözése a vidék elszegényedése és a vidéki munkalehetőségek megszúnése miatt.

15 Mivel Dani kiment a szobából, nem tudja, hogy édesanyja végül hogyan oldotta meg a helyzetet. 
ládtagok közül, akik előbújtak a környezetüknek vagy egy részének, senki sem találkozott elutasítással emiatt. A család fogalmának aktív kitágítása tehát nemcsak az LMBTQ emberek elfogadását segítheti eredeti családjukban, hanem azt is, hogy az azonos nemű párok magától értetődő módon integrálódjanak a tágabb közösségekbe.

\section{A cikkben szereplő interjúalanyok föbb demográfiai jellemzői}

\section{Azonos nemú párok tagjai}

\begin{tabular}{|c|c|c|c|c|c|c|}
\hline Álnév & Nem & Életkor* & $\begin{array}{c}\text { Származási telepü- } \\
\text { lés jellege }\end{array}$ & Jelenlegi lakóhely* & $\begin{array}{c}\text { Szülők társadalmi } \\
\text { státusza }\end{array}$ & $\begin{array}{c}\text { Saját } \\
\text { végzettség }\end{array}$ \\
\hline Andrea & nő & 60 & fóváros & kisváros & értelmiségi & felsőfokú \\
\hline Benő & férfi & 20 & kisváros & főváros & alsó középosztály ${ }^{* * *}$ & felsőfokú \\
\hline Dani & férfi & 20 & főváros & főváros & értelmiségi & felsőfokú \\
\hline Edmund & férfi & 20 & falu & falu & gazdálkodó & főiskolás \\
\hline Eszter & nő & 30 & főváros & főváros & alsó középosztály & főiskolás \\
\hline Félix & férfi & 20 & falu & kisváros & munkás & főiskolás \\
\hline Havana & nő & 20 & falu & nagyváros & gazdálkodó & 8 általános \\
\hline Ildi & nő & 30 & falu & Falu/föváros (kollégium) & munkás & főiskolás \\
\hline József & férfi & 50 & falu & főváros & munkás & felsőfokú \\
\hline Judit & nő & 30 & kisváros & főváros & alsó középosztály & felsőfokú \\
\hline Liza & nő & 30 & nagyváros & főváros & alsó középosztály & felsőfokú \\
\hline Norbi & férfi & 20 & főváros & főváros & alsó középosztály & felsőfokú \\
\hline Ribera & Nő & 30 & nagyváros & nagyváros & értelmiségi & felsőfokú \\
\hline Sándor & férfi & 30 & falu & falu & alsó középosztály & felsőfokú \\
\hline Törpi & nő & 30 & falu & főváros & munkásosztály & főiskolás \\
\hline Tünde & nő & 40 & Kisváros & főváros & munkásosztály & főiskolás \\
\hline Vándor & nő & 30 & nagyváros & kisváros & értelmiségi & felsőfokú \\
\hline Viola & nő & 30 & falu & főváros & gazdálkodó & középfokú \\
\hline
\end{tabular}

* Adatközlőim életkorát kerekítve közlöm (tehát a 30 lehet 28 vagy 34 éves), részben az anonimitás növelése érdekében, részben mert néhányukkal több interjú is készült és ezek között évek is eltelhettek.

** Ahol a személy a vele készített (utolsó) interjú idején lakott.

*** Ebbe a kategóriába soroltam azokat a középfokú végzettséggel vagy szakképesítéssel rendelkező embereket, akik adminisztrativ munkakörben, szolgáltatásokban stb. dolgoznak.

\section{Családtagok}

\begin{tabular}{|l|l|l|l|l|l|}
\hline Álnév & Nem & Életkor & Jelenlegi lakóhely & Végzettség & Rokoni viszony jellege \\
\hline Erzsébet & nő & 40 & külváros & középfokú & Zsóka édesanyja \\
\hline Ivett & nő & 20 & főváros & főiskolás & Kornélia húga \\
\hline Tulipán & nő & 50 & nagyváros & középfokú & Alexander édesanyja \\
\hline Zira & nő & 20 & külváros & középiskolás & Zsóka húga \\
\hline Zsuzsanna & nő & 70 & főváros & középfokú & Adorján édesanyja \\
\hline
\end{tabular}




\section{HIVATKOZÁSOK}

Anderson, B. (2006) Elképzelt közösségek. Gondolatok a nacionalizmus eredetéröl és elterjedéséröl. Budapest: L'Harmattan.

Austin, J. L. (1962) How to Do Things with Words. The William James Lectures delivered at Harvard University in 1955. Oxford: Clarendon Press.

Béres-Deák R. (2012) Szivárványcsaládok a magyar oktatásban. In Kozma T. - Perjés I. (szerk.) Új kutatások a neveléstudományokban. A munka és nevelés világa a tudományban. Budapest: MTA Pedagógiai Tudományos Bizottság - ELTE Eötvös Kiadó, 491-508.

Borgos A. (2014) Eltitkolt évek - mozaikok a magyar leszbikus herstoryból. Replika 2014/1-2 (85-86), 123-146.

Butler, J. (1991) Imitiation and Gender Subordination. In Fuss, D. (szerk.) Inside/Out. Lesbian Theories, Gay Theories. New York-London: Routledge, 13-37.

Butler, J. (1995) Burning Acts - Injurious Speech. In Parker, Andrew - Eve Kosofsky Sedgwick (szerk.) Performativity and Performance. New York - London: Routledge, 197-227.

Butler, J. (2005) Jelentős testek. A “szexus” diszkurzív korlátairól. Budapest: Új Mandátum Kiadó.

Butler, J. (2007) Problémás nem. Feminizmus és az identitás felforgatása. Budapest: Balassi Kiadó.

Davies, P. (1992) The Role of Disclosure in Coming Out among Gay Men. In Plummer, K. (szerk.) Modern Homosexualities. Fragments of lesbian and gay experience. London and New York: Routledge, 75-86.

D’Emilio, J. (1998 [1983]) Sexual Politics, Sexual Communities. The Making of a Homosexual Minority in the United States, 1940-1970. Chicago and London: University of Chicago Press.

Dombos T. - Takács J. - P. Tóth T. - Mocsonaki L. (2011) Az LMBT emberek magyarországi helyzetének rövid áttekintése. In Takács J. (szerk.) Homofóbia Magyarországon. Budapest: L’Harmattan, 35-54.

Esterberg, K. G. (1997) Lesbian and Bisexual Identities. Constructing Communities, Constructing Selves. Philadelphia: Temple University Press.

Fél E. - Hofer T. (1969) Proper Peasants. Traditional Life in a Hungarian Village. New York: Wenner-Green Foundation for Anthropological Research Inc.

Foucault, M. (1999) A szexualitás története I. A tudás akarása. Budapest: Atlantisz.

Franklin, K (1998) Unassuming Motivations: Contextualizing the Narratives of Antigay Assailants. In Herek, G. M. (ed.) Stigma and Sexual Orientation. Understanding Prejudice against Lesbians, Gay Men, and Bisexuals. Thousand Oaks - London - New Delhi: SAGE, 1-23.

Goffman, E. (1974) Stigma. Notes on the Management of Spoiled Identity. New York: Jason Aronson.

Herdt, G. - Koff, B. (2000) Something to Tell You. The Road Families Travel when a Child is Gay. New York: Columbia University Press.

Herek, G. M. (1997) Heterosexuals' Attitudes toward Lesbians and Gay Men: Does Coming Out Make a Difference? In Duberman, M. (szerk.) A Queer World. The Center for Lesbian and Gay Studies Reader. NY-London: NY University Press, 331-344.

Kuhar, R. (2007) The Family Secret: Parents of Homosexual Sons and Daughters. In Kuhar, R. - Takács J. (szerk.) Beyond the Pink Curtain. Everyday Life of LGBT People in Eastern Europe. Ljubljana: Mirovni Inštitut, 35-48.

Lawler, S. (2000) Mothering the Self. Mothers, daughters, subjects. London - New York: Routledge.

Plummer, K. (1997) Telling Sexual Stories. Power, Change and Social Worlds. London-New York: Routledge.

Powell, B. - Bolzendahl, Ch. - Geist, C. - Carr Steelman, L. (2010) Counted Out. Same-Sex Relations and Americans' Definitions of Family. New York: Russell Sage Foundation.

Richards, D. A. J. (1999) Identity and the Case for Gay Rights. Race, Gender and Religion as Analogies. Chicago and London: University of Chicago Press.

Sedgwick, E. K. (2011) A rejtőzködés episztemológiája. Café Bábel 62, 23-36.

Somlai P. (2002) Húsz év. Családi kapcsolatok változásai a 20. század végi Magyarországon. Budapest: Új Mandátum.

Sontag, S. (1999) A fényképezésről. Budapest: Európa Kiadó.

Stewart, M. (1997) The Time of the Gypsies. Oxford - Boulder: Westview Press.

Stone, L. (2004) Has the World Turned? Kinship and Family in the Contemporary American Soap Opera. In Parkin, R. - Stone L. (szerk.) Kinship and Family: An Anthropological Reader. Boston: Blackwell, 395-407.

Takács J (2011) Homofóbia Magyarországon és Európában. In Takács J. (szerk.) Homofóbia Magyarországon. Budapest: L’Harmattan, $15-34$. 
Takács J. - Mocsonaki L. - P. Tóth T. (2008) A meleg, leszbikus, biszexuális és transznemű (LMBT) emberek társadalmi kirekesztettsége Magyarországon. Esély 3/2008, 16-54.

Tóth E. Zs. (2008) „Gábor, csináljunk gyereket, hadd vessen cigánykereket!” A megesett lánytól az egyedülálló anyáig - a lányanyák megítélésének változása a szocialista időszakban. In Bakó B. - Tóth E. Zs. (szerk.) Határtalan nők. Kizártak és befogadottak a nói társadalomban. Budapest: Nyitott Könyvmúhely, 338-357.

Tóth L. (1993) A homoszexualitásról. Budapest: T-Twins.

Troiden, R. (2004) A Model of Homosexual Identity Formation in Social Perspective. In Parkin, R. - Stone, L. (szerk.) Kinship and Family. An Anthropological Reader. Boston: Blackwell, 260-278.

Weston, K. (1991) Families We Choose. Lesbians, Gays, Kinship. New York: Columbia University Press.

Weston, K. (1998) Longslowburn. Sexuality and Social Science. New York - London: Routledge. 